\title{
Models of ice-atmosphere interactions for the Greenland ice sheet
}

\author{
Roger J. Braithwaite \\ Department of Geography, University of Manchester, Manchester M13 9PL, England
}

\begin{abstract}
Simple models to calculate melt and refreezing are reviewed. Both degree-day and energy-balance models can give distributed melt inputs to icedynamics models but have only been tested extensively in West Greenland, and more data are needed from the remoter parts of Greenland. The energy-balance model is more realistic but needs input data that are not generally available over the whole ice sheet. On the other hand, degree-day factors vary from situation to situation although a value of about $8 \mathrm{~kg} \mathrm{~m}^{-2} \mathrm{~d}^{-1}$ deg ${ }^{1}$ for ice ablation is a reasonable first approximation as assumed in recent ice-dynamics models. Meltwater refreezing in the accumulation area can be modelled very simply but more detailed physical models are needed to describe the shifts in accumulation zones under different climates.
\end{abstract}

\section{INTRODUCTION}

The spatial distribution and time variations of mass balance are needed over the whole Greenland ice sheet as inputs to ice-dynamics models. As such models must describe the dynamics of the ice sheet under past, present and (likely) future climates, the mass balance must be modelled in terms of climate variables, which are themselves accessible to direct measurement and to modelling.

For the purposes of the present paper, the specific balance $b$ is given by

$$
b=c-a
$$

where $c$ is the accumulation and $a$ is the ablation. Ablation is defined here as positive, because this is more convenient than the negative ablation recommended by Anonymous (1969). The present-day distribution of accumulation is reasonably well-known (Ohmura and Reeh, 1991) and the present paper reviews progress and problems with calculating the ablation component of the surface balance. Ablation $a$ is given by

$$
a=m-r
$$

where $m$ is the melt and $r$ is the refreezing of meltwater. Melt can be calculated from temperature data by the degree-day model and from more extensive climate data by the energy-balance model.

All quantities in Equations (1) and (2) are annual specific balances in $\mathrm{kg} \mathrm{m}^{-2} \mathrm{a}^{-1}\left(\mathrm{~mm} \mathrm{a}^{-1}\right)$, and must depend explicitly on climate (and accumulation if that is prescribed). The sites of recent ablation-climate studies in Greenland are shown in Figure 1.

\section{DEGREE-DAY MODEL}

The degree-day model was first suggested by Finsterwalder and Schunk (1887) for an Alpine glacier and has been field-tested in Greenland by Braithwaite and Olesen (1985, 1989) and Braithwaite (1995b). Aside from being used to plan hydropower stations in Greenland KernHansen, 1988; Braithwaite and Thomsen, 1989), the degree-day model is used to drive ice-dynamics models of Northern Hemisphere ice sheets Payne and Sugden, 1990; Huybrechts and others, 1991; Letréguilly and others, 1991; Huybrechts, 1994; Fabre and others, 1995; Greve and Hutter, 1995; Huybrechts and T'siobbel, 1995) and to calculate the effects of climate change on water resources in Scandinavia (Johannesson and others, 1993; Laumann and Reeh, 1993; Johannesson and others, 1995).

The melt $m$ at a certain point during a certain period is given by

$$
m=k \cdot P D D
$$

where PDD is the sum of positive temperatures at the same point for the same period and the parameter $k$ is the degree-day factor. Strictly speaking, PDD should be calculated as the positive sum of temperature series, e.g. data collected several times in each day, but can be estimated from monthly (Braithwaite, 1980, 1985) or annual temperatures (Reeh, 1991).

If the total melt $m$ is made up of snow melt $m_{\mathrm{s}}$ and ice melt $m_{\mathrm{i}}$, separate degree-day factors should be applied to the two phases:

$$
m_{\mathrm{s}}=k_{\mathrm{s}} \cdot P D D_{\mathrm{s}}
$$




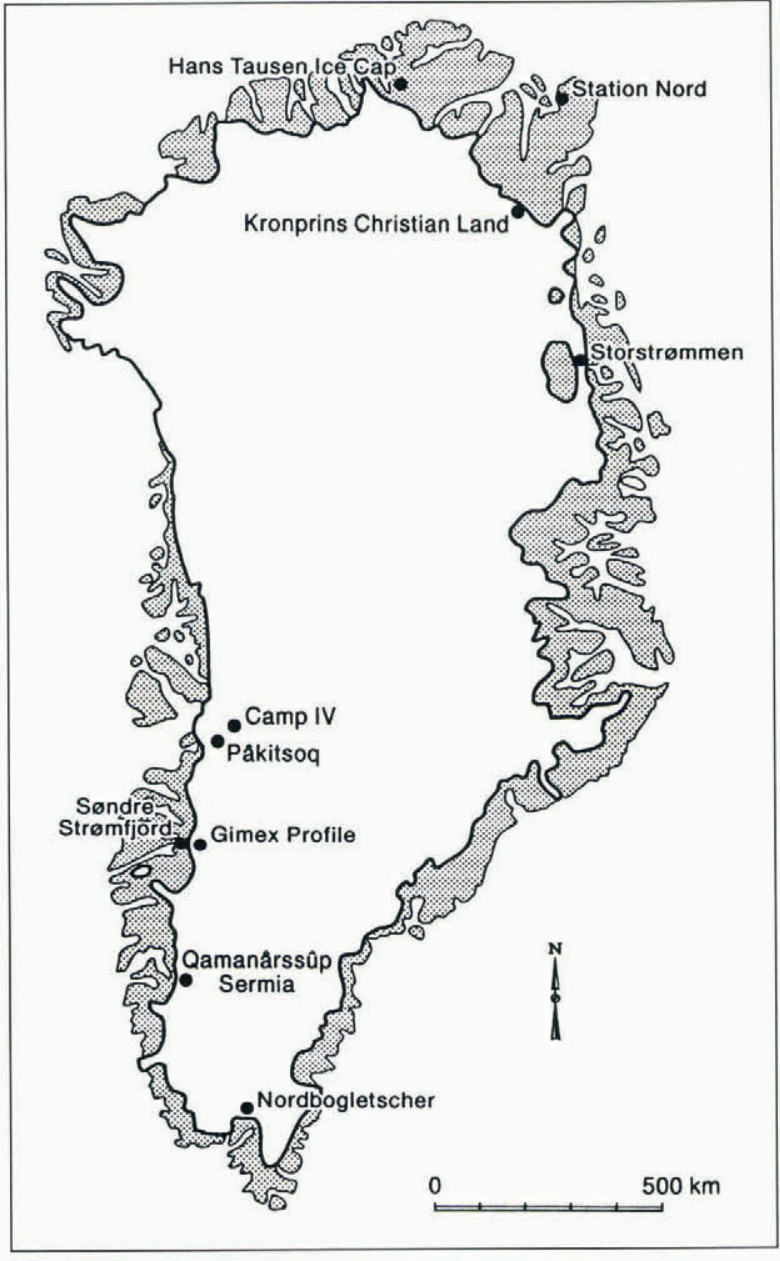

Fig. 1. Locations of glaciological studies in Greenland referred to in the text.

and

$$
m_{\mathrm{i}}=k_{\mathrm{i}} \cdot P D D_{\mathrm{i}}(5)
$$

where $k_{\mathrm{s}}$ and $k_{\mathrm{i}}$ are degree-day factors for snow and ice, respectively, and $P D D_{\mathrm{s}}$ and $P D D_{\mathrm{i}}$ are degree-day sums for the periods of snow and ice melt.

The most recent compilation of field data from the sites in Figure 1 (Braithwaite, 1995b) does not support a single and universal degree-day factor for ice ablation, although the value of $8 \mathrm{~mm} \mathrm{~d}^{-1} \mathrm{deg}^{-1}$, assumed for recent ice-dynamics modelling (Huybrechts and others, 1991; Letréguilly and others, 1991; Huybrechts, 1994), is a reasonable first approximation.

The degree-day factor for snow in Greenland is only about $40 \%$ of the factor for ice (Table 1) while Scandinavian glaciers show a higher value of about $70 \%$. As energy-balance modelling shows that degree-day factors are strongly controlled by albedo (Braithwaite, 1995b, fig. 6), the differences in snow and ice degree-day factors may reflect a smaller albedo contrast on the Scandinavian glaciers than on the two Greenland glaciers.

\section{ENERGY-BALANGE MODEL}

The melt $m$ is calculated from the available energy at the
Table 1. Positive degree-day factors for ice and snow ablation calculated by mass-balance (MB) and energybalance (EB) modelling. Units are $\mathrm{mmd}^{\prime} \mathrm{deg}^{-}$.

$\begin{array}{ccccc}\text { Model Ice Snow Ratio Reference } \\ \\ (1) & (2) & (2 / 1)\end{array}$

Greenland

$\begin{array}{llllll}\text { Nordbogletscher } & \text { MB } & 7.2 & 2.5 & 0.35 & 1 \\ & \text { EB } & 8.1 & 2.9 & 0.36 & 2 \\ \text { Qamanârssûp sermia } & \text { MB } & 7.3 & 2.8 & 0.38 & 3 \\ & \text { EB } & 8.3 & 3.7 & 0.44 & 2 \\ \text { Iceland and Norway } & & & & & \\ \text { Sátujökull } & \text { MB } & 7.7 & 5.6 & 0.73 & 3 \\ \text { Nigardsbreen } & \text { MB } & 6.4 & 4.4 & 0.69 & 3 \\ & \text { MB } & 5.5 & 4.0 & 0.73 & 4 \\ \text { Allfotbreen } & \text { MB } & 6.0 & 4.5 & 0.75 & 4 \\ \text { Hellstugubreen } & \text { MB } & 5.5 & 3.5 & 0.64 & 4\end{array}$

1. Braithwaite and Olesen (1988).

2. Braithwaite (1956).

3. Jøhannesson and others (1995)

4. Laumann and Reeh (1993).

glacier surface and

$$
m L+g h=s w+l w+s h+l h,
$$

where $L$ is the latent heat of fusion, $g h$ is the ground heat flux, $s w$ is the net shortwave radiation, $l w$ is the net longwave radiation, $s h$ is the sensible-heat flux and $l h$ is the latent-heat flux.

Despite the apparent simplicity of Equation (6), the energy balance represents a complex of physical processes (Paterson, 1994, chapter 4). The essence of energybalance modelling is to estimate each term in the balance from a few simple climate elements, e.g. global radiation, cloud amount, air temperature, wind speed and humidity (Braithwaite and Olesen, 1990). However, even these simple data are not available over most of the Greenland ice sheet and their past and future variations are hardly known. One must therefore distinguish between a model for a well-instrumented site (Braithwaite and Olesen, 1990; Wal and Russell, 1994) and a model for the whole ice sheet (Oerlemans, 1991; Wal and Oerlemans, 1994), which requires further simplification to avoid using data that are not available.

The above point can be illustrated by a relatively simple method to calculate sensible-heat flux based on Ambach (1986) as modified by Paterson (1994, p. 65) and is

$$
s h=\left(1.29 \times 10^{-2}\right) A P u\left(T-T_{\mathrm{s}}\right),
$$

where $A$ is a dimensionless transfer coefficient, $P$ is atmospheric pressure and $u$ and $T$ are wind speed and temperature a couple of metres above the glacier surface. $T_{\mathrm{s}}$ is the surface temperature of the glacier, which is $0^{\circ} \mathrm{C}$ for melting ice, and the numerical factor lumps together some constants; see Paterson (1994, p. 65) for details. 

by

For neutral turbulence, the transfer coefficient is given

$$
A=\frac{k^{2}}{\left[\ln \left(z / z_{\mathrm{OU}}\right)\right] \cdot\left[\ln \left(z / z_{\mathrm{OT}}\right)\right]},
$$

where $k$ is von Karmen's constant $(0.41), z$ is the instrument height, $z_{\mathrm{OU}}$ is the surface roughness for wind speed and $z_{\mathrm{OT}}$ is the surface roughness for temperature. The approach can also be extended to stable turbulence by using log-linear profiles instead of logarithmic profiles (Munro, 1989; Braithwaite, 1995a). A is of the order of 0.002 for ice and 0.001 for snow using the surface roughness given by Ambach (1986).

The validity of the above approach is still open to debate, especially on the assumed wind and temperature profiles (Grainger and Lister, 1966) and choice of parameters (Forrer and Rotach, 1994; Henneken, 1994; Ohmura and others, 1994), but it does offer a rational way to calculate sensible-heat fluxes from temperature and wind-speed data. This is useful if these data are available but the wind-speed distribution over the ice sheet is almost unknown in contrast to the temperature distribution (Ohmura, 1987). One solution is to follow Kuhn (1979) and calculate sensible-heat flux from temperature alone so that

$$
s h=\sigma\left(T-T_{\mathrm{s}}\right),
$$

where $\alpha$ is a bulk heat-transfer coefficient.

This bulk approach has been used in Greenland with $\alpha$ values of $10-15 \mathrm{~W} \mathrm{~m}^{-2} \mathrm{~K}^{-1}$ (Oerlemans, 1991; Oerlemans and others, 1993; Wal and Oerlemans, 1994) without any discussion of the different values used, and presumably the $\alpha$ values are found by model tuning. Comparison of Equations (7) and (9) suggest that the $\alpha$ parameter depends on mean wind conditions and, as mean wind speeds in Greenland lie in the general range 3-8 $\mathrm{m} \mathrm{s}^{-1}$ (Broeke and others, 1994; Konzelmann and Braithwaite, 1995), $\alpha$ may vary by more than a factor of 2 , depending upon locality and period. The bulk approach is probably valid but better documentation and critical testing are needed to be convincing.

There is not enough space here for a critical discussion of the other energy-balance terms but there seems to be a similar pattern: simplified methods are needed to calculate the energy balance for the whole ice sheet but these methods should be critically tested and better documented. This must be especially the case for the shortwave radiation and albedo, where some highly sophisticated formulations are used, although one knows that there are very little data, e.g. Konzelmann (1994) listed radiation data from only nine short-term stations in Greenland.

\section{MELTWATER REFREEZING}

Refreezing $r$ is generally small for a well-drained melting ice surface, where water can run off before it has time to refreeze. However, meltwater from a melting snow surface, e.g. as in the accumulation area of the ice sheet, infiltrates the underlying snow layer and refreezes if or when it encounters cold snow. The temperature of the lower snow layer is raised by the latent heat released by the refreezing and may reach $0{ }^{\circ} \mathrm{C}$, after which refreezing ceases at that level. Infiltrating meltwater thereafter reaches increasingly deeper layers until it is all refrozen, or until it meets an impermeable surface at the melting point, after which it may flow laterally along this surface.

The concept of different zones in the accumulation area, developed by P.A. Shumskii, C. S. Benson and F. Müller (Paterson, 1994, p. 9-12), is important for modelling refreezing, and ice-sheet models must take account of the shifts of these zones in response to climate changes. The flow of meltwater within cold snow involves a complex interplay of hydraulics and heat transfer (Colbeck, 1976; Illangasekare and others, 1990), but more conceptual approaches can be taken (Pfeffer and others, 1991; Braithwaite and others, 1994). The latter is summarized below.

A surface layer of firn is wetted by meltwater during the summer down to a certain depth, below which the firn remains dry although it has been wetted in earlier years. The density at the bottom of this wetted layer $\rho_{2}$ is a function of melt $m$ and accumulation $c$ and

$$
\rho_{2}=\rho_{0} /(1-(m / c)),
$$

where $\rho_{0}$ is the density of surface snow before melting starts. Alternatively, the melting $m$ required to achieve the density $\rho_{2}$ is:

$$
m / c=\left(\rho_{2}-\rho_{0}\right) / \rho_{2} .
$$

There is a run-off limit within the lower accumulation area of the Greenland ice sheet, above which all meltwater is refrozen so there is no run-off. At this runoff limit the whole surface layer of firn is completely wetted by the end of the summer and the underlying material is impermeable to meltwater, i.e. the density $\rho_{2}$ refers to ice. The run-off limit defined in this way is above the firn limit as there is some run-off from within the firn area (LaChapelle, 1955), but the wet firn layer must be fairly shallow for run-off to occur, i.e. not thicker than the few metres of annual meltwater penetration (Trabant and Mayo, 1985).

Using the snow and ice densities of 375 and $890 \mathrm{~kg} \mathrm{~m}^{-3}$ (Braithwaite and others, 1994) the ratio $\mathrm{m} / \mathrm{c}$ is about 0.6 at the run-off limit. Values reported in the literature are 0.7 (Pfeffer and others, 1991), 0.6 without explanation (Huybrechts and others, 1991) and 0.4 (Shumskii, 1964), where differences mainly reflect different choices of density. The ablation is given by

$$
\begin{array}{ll}
a=0 & m \leq 0.6 c \\
a=m-0.6 c & m>0.6 c .
\end{array}
$$

Meltwater refreezing must be included in ice-sheet models to calculate the correct altitude of the equilibrium line (ELA), where $a=c$. This occurs at $m=c$ without refreezing and at $m=1.6 c$ with refreezing. The effect of refreezing in mass-balance models is to lower the ELA in West Greenland by $100-200 \mathrm{~m}$ a.s.l.

Considering the remaining uncertainties in modelling the melt $m$, Equation (6) is probably good enough to describe the rapid densification in the near-surface firn layer due to refreezing, and presumably further densification at greater depths can be described by dry-snow 
models like that of Herron and Langway (1980). However, this approach assumes that deeper firn layers are far below the melting point while a truly dynamic model, describing the evolution of the Greenland ice sheet under a variety of different climates, should calculate firn temperatures. For example, could the deeper firn layers be slowly warmed up to the melting point under a warmer climate, with a consequent increased run-off to the sea? This can only be answered by a detailed physical model of refreezing in the near-surface firn layers, but such a model will be hard to verify due to the practical difficulty of working in the wet snow zone (Braithwaite and Laternser, 1993).

\section{DISGUSSION}

Both degree-day and energy-balance models can give distributed inputs to ice-dynamics models but have only been tested extensively in West Greenland. The energybalance model seems more realistic than the degree-day model but needs input data that are not generally available over the whole ice sheet, while the parameters in the degree-day model can vary from one situation to another.

The models are not exclusive alternatives but available tools for ice-sheet modellers. For example, the simulation of degree-day factors by energy-balance modelling (Braithwaite, 1995b) shows how the models can be used together. More fundamentally, both models will be improved by data collection in the remoter parts of Greenland, where conditions are less well known than in West Greenland. For example, reconnaissance energybalance studies in north Greenland show that sublimation from the glacier surface and heat conduction into the ice are both much larger than in West Greenland (Table 2), greatly reducing the energy that would otherwise be available for melting.

In addition to further data from north Greenland (cold-dry), similar studies should also be made in southeast Greenland (warm-wet) to sample ablation conditions in a humid environment. The increased income of longwave radiation and heat supply from condensation probably causes increased ablation there.

Extra data collections from both north and south-east Greenland are probably a minimum requirement for models to describe fully the diverse conditions found over the present Greenland ice sheet, and which must have prevailed at different periods in the past. In view of the expense and logistic difficulties of working in remote areas, long-term programmes of mass-balance measurements (with little or no parallel collection of meteorological data) as in the Alps and in Scandinavia are not recommended. A greater return on investments will be achieved by relatively short periods of detailed measurements of ablation and climate, either on a reconnaissance basis (Konzelmann and Braithwaite, 1995) or in the form of full glacier-meteorology experiments (Oerlemans and Vugts, 1993; Ohmura and others, 1994).

The calculation of melt within high resolution GCMs (global climate models) will soon be realistic (Ohmura and others, 1994) but, here again, it will be necessary to
Table 2. Calculated energy balance $\left(\mathrm{Wm}^{-2}\right)$ at four sites in Greenland: Nordbogletscher (NBG), Qamanârssûp sermia (QAM), Kronprins Christian Land (KPCL) and Hans Tausen Ice Cap (HTIC)

\section{NBG QAM KPCL HTIC}

\begin{tabular}{lrrrr}
\hline Latitude ${ }^{\circ} \mathrm{N}$ & 61 & 64 & 80 & 83 \\
Days & 415 & 512 & 20 & 35 \\
Altitude (m a.s.l.) & 880 & 790 & 380 & 540 \\
Reference & 1 & 1 & 2 & 3 \\
Short-wave radiation & 111 & 128 & 165 & 116 \\
Long-wave radiation & -32 & -25 & 43 & -32 \\
Sensible-heat flux & 32 & 62 & 88 & 27 \\
Latent-heat flux & 2 & -6 & -36 & -24 \\
Unexplained & -2 & 2 & 2 & 1 \\
Ablation & 111 & 161 & 158 & 71 \\
Ground-heat flux & $0 ?$ & $0 ?$ & 18 & 18
\end{tabular}

1. Braithwaite and Olesen (1990).

2. Konzelmann and Braithwaite (1995).

3. Geological Survey of Greenland (unpublished data).

test the results with data from different parts of Greenland. Remote sensing can also be expected to play a part, e.g. for mapping large-scale albedo variations (Haefliger and others, 1993).

\section{ACKNOWLEDGEMENTS}

The author's recent research has been supported by the European Union through contracts to the Geological Survey of Greenland (GGU): EPOC-CT90-0015 for 1991-93 and EV5V-CT91-0051 for 1992-94. Attendance at the 1995 EISMINT symposium in Chamonix was supported by the Arts Faculty, The University of Manchester (Account No. 6/VBF/RA/002).

\section{REFERENCES}

Ambach, W. 1986. Nomographs for the determination of meltwater from snow- and ice surfaces. Berichte des. NaturwissenschaflichMedizinischen Vereins in Innsbruck 73, 7-15.

Anonymous. 1969. Mass-balance terms. J. Glaciol., 8(52), 3-7.

Braithwaite, R.J. 1980. Regional modelling of ablation in West Greenland. Gronlands Geologiske Undersogelse Rapport 98.

Braithwaite, R. J. 1985. Calculation of degree-days for glacier-climate research. Z. Gletscherkd. Glazialgeol., 20, 1984, 1-8.

Braithwaite, R.J. 1995a. Aerodynamic stability and turbulent sensibleheat flux over a melting ice surface, the Greenland ice sheet. . . Glaciol., 41(139), 562-571.

Braithwaite, R.J. 1995b. Positive degree-day factors for ablation on the Greenland ice sheet studied by energy-balance modelling. f. Glaciol., 41 137), 153-160.

Braithwaite, R.J. and M. Laternser. 1993. Measurements of firn density in the lower accumulation area of the Greenland ice sheet: EPOCH 1992. Gronlands Geologiske Undersogelse Rapport 159, 6265.

Braithwaite, R.J. and O.B. Olesen. 1985. Ice ablation in West Greenland in relation to air temperature and global radiation. Z. Gletscherkd. Glazialgeol., 20, 1984, 155-168.

Braithwaite, R.J. and O. B. Olesen. 1988. Winter accumulation reduces summer ablation on Nordbogletscher, south Greenland. Z. Gletscherkd. Glazialgeol., 24 (1), 21-30.

Braithwaite, R. J. and O. B. Olesen. 1989. Calculation of glacier ablation from air temperature, West Greenland. In Oerlemans, J., ed. Glacier 
fluctuations and climatic change. Dordrecht, etc., Kluwer Academic Publishers, 219-233.

Braithwaite, R.J. and O.B. Olesen. 1990. A simple energy-balance model to calculate ice ablation at the margin of the Greenland ice sheet. 7. Glaciol., 36 (123), 222-228.

Braithwaite, R.J. and H. H. Thomsen. 1989. Simulation of run-off from the Greenland ice sheet for planning hydro-electric power, Ilulissat/ Jakobshavn, West Greenland. Ann. Glaciol., 13, $12-15$.

Braithwaite, R.J., M. Laternser and W. T. Pfeffer. 1994. Variations of near-surface firn density in the lower accumulation area of the Greenland ice sheet, Pâkitsoq, West Greenland. J. Glaciol., 40 (136), $477-485$.

Broeke, M. R. vanden, P. G. Duynkerke and J. Oerlemans, 1994. The observed katabatic flow at the edge of the Greenland ice sheet during GIMEX-91. Global and Planetary Change, 9(1-2), 3-15.

Colbeck, S. C. 1976. An analysis of water flow in dry snow. Water Resour. Res., $12(3), 523-527$.

Fabre, A., A. Letréguilly, C. Ritz and A. Mangeney. 1995. Greenland under changing climates: sensitivity experiments with a new threedimensional ice-sheet model. Ann. Glaciol., 21, 1-7.

Finsterwalder, S. and H. Schunk. 1887. Der Suldenferner. Zeilschrift des Deutschen und Österreichischen Alpenvereins, 18, 70-89.

Forrer, J. and M. Rotach. 1994. Comparison between measured and calculated turbulent fluxes. Gronlands Geologiske Undersogelse. Ser. Open File 94 13, $36-39$.

Grainger, M. E. and H. Lister. 1966. Wind speed, stability and eddy viscosity over melting ice surfaces. F. Glaciol., 6 43), 101-127.

Greve, R. and K. Hutter. 1995. Polythermal three-dimensional modelling of the Greenland ice sheet with varied geothermal heat flux. Ann. Glaciol., 21, 8-12.

Haefliger, M., K. Steffen and C. Fowler. 1993. AVHRR surface temperature and narrow-band albedo comparison with ground measurements for the Greenland ice sheet. Amn. Glaciol., 17, 49-54.

Henneken, E. A. 1994. On the use of the profile method on the Greenland ice sheet. Gronlands Geologiske Undersogelse. Ser. Open File $94-13,57-59$.

Herron, M.M. and C. C. Langway, Jr. 1980. Firn densification: an empirical model. f. Glaciol., 25 (93), 373-385.

Huybrechts, P. 1994. The present evolution of the Greenland ice sheet: an assessment by modelling. Global and Planetary Change, 9 (1-2), 39 51.

Huybrechts, P. and S. T'siobbel. 1995. Thermomechanical modelling of Northern Hemisphere ice sheets with a two-level mass-balance parameterization. Ann. Glaciol., 21, 111-116.

Huybrechts, P., A. Letréguilly and N. Reeh. 1991. The Greenland ice sheet and greenhouse warming. Global and Planetary Change, 3 4), 399 412 .

Illangasekare, T.H., R.J. Walter, Jr, M. F. Meier and W. T. Pfeffer. 1990. Modeling of meltwater infiltration in subfreezing snow. Water Resour. Res., 26 5), 1001-1012.

Jóhannesson, T., O. Sigurdsson, T. Laumann and M. Kennett. 1993. Degree-day glacier mass balance modelling with applications to glaciers in Iceland and Norway. Reykjavik, (Nordic Hydrological Programme. Rapport 33.) Orkustofnun.

Jóhannesson, T., O. Sigurdsson, T. Laumann and M. Kennett. 1995. Degree-day glacier mass-balance modelling with applications to glaciers in Iceland, Norway and Greenland. f. Glaciol., 41 138), 345358.

Kern-Hansen, C. 1988. Hydrological background of a glacier-influenced hydropower station in Greenland. Nord. Hydrol., 19 4), 269280.
Konzelmann, T. 1994. Radiation conditions on the Greenland ice sheet. Zürcher Geogr. Schr. 56.

Konzelmann, T. and R.J. Braithwaite. 1995. Variations of ablation, albedo and energy balance at the margin of the Greenland ice sheet, Kronprins Christian Land, eastern North Greenland. J. Glaciol., $41(137), 174-182$.

Kuhn, M. 1979. On the computation of heat transfer coefficients from energy-balance gradients on a glacier. 7. Glaciol., 22 87), 263-272.

LaChapelle, E. 1955. Ablation studies in the Mint Julep area, southwest Greenland. Project Mint Julep. Part II. Special Scientific Reports. Maxwell Air Force Base, AL, Air University. Arctic, Desert, Tropic Information Center, 51-72. Publication A-104B.

Laumann, T. and N. Reeh. 1993. Sensitivity to climate change of the mass balance of glaciers in southern Norway. f. Glaciol., 39 133), $656-665$.

Letréguilly, A., P. Huybrechts and N. Reeh. 1991. Steady-state characteristics of the Greenland ice sheet under different climates. J. Glaciol., 37 125), 149-157.

Munro, D.S. 1989. Surface roughness and bulk heat transfer on a glacier: comparison with eddy correlation. f. Glaciol., 35 (121), 343 348.

Oerlemans, J. 1991. The mass balance of the Greenland ice sheet: sensitivity to climate change as revealed by energy-balance modelling. Holocene, 1 (1), $40-49$.

Oerlemans, J. and H.F. Vugts. 1993. A meteorological experiment in the melting zone of the Greenland ice sheet. Bull. Am. Meteorol. Soc., $74(3), 355-365$.

Oerlemans, J., R.S. van de Wal and L. A. Conrads. 1993. A model for the surface balance of ice masses: Part II. Application to the Greenland ice sheet. Z. Gletscherkd. Glazialgeol., 27/28, 1991/1992, 85 96.

Ohmura, A. 1987. New temperature distribution maps for Greenland. Z. Gletscherkd. Glazialgeol., 23 1), 1-45.

Ohmura, A. and N. Reeh. 1991. New precipitation and accumulation maps for Greenland. J. Glaciol., 37 (125), 140-148.

Ohmura, A. and 6 others. 1994. Energy balance for the Greenland ice sheet by observation and model computation. International Association of Hydrological Sciences Publication 223. (Symposium at Yokohama 1993 - Snow and Ice Covers: Interactions with the Almosphere and Ecosystems), $85-94$.

Paterson, W.S. B. 1994. The physics of glaciers. Third edition. Oxford, etc., Elsevier Science Ltd.

Payne, A. and D. Sugden. 1990. Climate and the initiation of maritime ice sheets. Amn. Glaciol., 14, 232-237.

Pfeffer, W. T., M. F. Meier and T. H. Illangasekare. 1991. Retention of Greenland runoff by refreezing: implications for projected future sea level change. J. Geophys. Res., 96 (C12), 22,117-22,124.

Reeh, N. 1991. Parameterization of melt rate and surface temperature on the Greenland ice sheet. Polarforschung, 59 3), 113-128.

Shumskii, P.A. 1964. Principles of structural glaciology. New York, Dover Publications.

Trabant, D. C. and L. R. Mayo. 1985. Estimation and effects of internal accumulation on five glaciers in Alaska. Ann. Glaciol., 6, 113-117.

Wal, R.S. W. van de and J. Oerlemans. 1994. An energy balance model for the Greenland ice sheet. Global and Planetary Change, 9 1-2), 115 131.

Wal, R. S. W. vande and A.J. Russell. 1994. A comparison of energy balance calculations, measured ablation and meltwater runoff near Sondre Stromfjord, West Greenland. Global and Planetary Change, 9 (2), $29-38$. 